\title{
Pengaruh dekomposisi Trichoderma virens pada berbagai jenis kompos kotoran ternak untuk menekan penyakit busuk pangkal batang bawang merah
}

\author{
The effect of Trichoderma virens decomposition on various types of manure compost \\ to suppress shallot stem rot disease \\ Rosmini $^{1)}$, Nur Hayati ${ }^{1)}$, Burhanuddin Nasir ${ }^{1)}$, Flora Pasaru ${ }^{1)}$, Sri Anjar Lasmini ${ }^{1)^{*}}$ \\ ${ }^{1}$ Fakultas Pertanian Universitas Tadulako, Palu, Indonesia \\ *Email korespondensi: srianjarlasmini@gmail.com
}

Informasi artikel: Dikirim: 06/06/2020 Ditinjau: 06/06/2020 Disetujui: 16/08/2020

\section{cc) (7)}

Copyright (c) 2020 Rosmini, Nur Hayati, Burhanuddin Nasir, Flora Pasaru, Sri Anjar Lasmini
ABSTRACT: Palu Valley shallot production is still very low namely 5.31 tonnes/ha when compared to national production which reaches 9.7 tonnes / ha, this is due to the attack of the base stem rot disease caused by Fusarium oxsyporum f.sp. cepae. This study aims to determine the effect of various types of organic fertilizer decomposed by Trichoderma virens on the incidence of stem rot disease and shallot yields. The research was conducted at the Laboratory of Pests and Plant Diseases, Faculty of Agriculture, Tadulako University, and shallot planting in Oloboju Village, Sigi Biromaru District, Sigi Regency, Central Sulawesi Province and lasted from March 2018 to August 2018. This research used a Randomized Block Design (RBD) with five treatments consisting of, without organic fertilizer (BO), cow manure 10 tons/ha + Trichoderma virens $100 \mathrm{~g} / \mathrm{L}$ (B1), chicken manure 10 tons $/$ ha $+T$. virens $100 \mathrm{~g} / \mathrm{L}$ (B2), goat manure 10 tons/ha $+T$. virens $100 \mathrm{~g} / \mathrm{L}$ (B3), and petroganic 5 tons/ha+ T. virens $100 \mathrm{~g} / \mathrm{L}$ (B4). The results showed that the use of 10 tons/ha cow manure decomposed by $T$. virens (B1) can reduce the intensity of stem rot disease on the Palu Valley shallot which is $5.61 \%$ to be $1.88 \%$ ( $3^{\text {rd }}$ week) and $2.89 \%$ to be $0.98 \%$ ( $7^{\text {th }}$ week), and increase shallot yield from 4.09 tons/ha to be 7.48 tons/ ha.

Keywords: organic fertilizer, shallots, Trichoderma virens

ABSTRAK: Produksi bawang merah Lembah Palu masih sangat rendah yakni 5,31 ton/ha bila dibandingkan dengan produksi nasional yang mencapai 9,7 ton/ha, hal tersebut karena adanya serangan penyakit penyakit busuk pangkal batang yang disebabkan oleh Fusarium oxsyporum f.sp. cepae. Penelitian ini bertujuan untuk mengetahui pengaruh berbagai jenis kompos kotoran ternak yang didekomposisi Trichoderma virens terhadap kejadian penyakit busuk pangkal batang dan produksi bawang merah. Penelitian dilaksanakan di Laboratorium Hama dan Penyakit Tumbuhan, Fakultas Pertanian, Universitas Tadulako dan di lahan pertanaman bawang merah di Desa Oloboju, Kecamatan Sigi Biromaru, Kabupaten Sigi, Provinsi Sulawesi Tengah dan berlangsung sejak Maret 2018 sampai dengan Agustus 2018. Penelitian menggunakan Rancangan Acak Kelompok (RAK) dengan lima perlakuan yang terdiri atas, tanpa pupuk organik (B0), pupuk kandang sapi 10 ton/ha + Trichderma virens $100 \mathrm{~g} / \mathrm{L}$ (B1), pupuk kandang ayam 10 ton/ha + T. virens 100g/L (B2), pupuk kandang kambing 10 ton/ha $+\mathrm{T}$. virens $100 \mathrm{~g} / \mathrm{L}$ (B3), dan pupuk petroganik 5 ton/ha $+\mathrm{T}$. virens 100g/L (B4). Hasil penelitian menujukkan bahwa penggunaan pupuk kotoran sapi 10 ton/ha yang didekomposisi T. virens (B1) dapat menekan intensitas serangan penyakit busuk pangkal batang pada tanaman bawang merah Lembah Palu yakni yakni 5,61\% menjadi 1,88\% (minggu ke-3) dan 2,89\% menjadi 0,98\% (minggu ke7), serta meningkatkan produksi bawang merah yakni dari 4,09 ton/ha menjadi 7,48 ton/ha.

Kata kunci: bawang merah, pupuk organik, Trichoderma virens

Sitasi: Lasmini, S. A., Rosmini, R., Hayati, N., Nasir, B., \& Pasaru, F. (2020). Pengaruh dekomposisi Trichoderma virens pada berbagai jenis kompos kotoran ternak untuk menekan penyakit busuk pangkal batang bawang merah. AGROMIX, 11(2), 177-188. https://doi.org/10.35891/agx.v11i2.2081 


\section{PENDAHULUAN}

Bawang merah (Allium ascalonicum L.) merupakan salah satu komoditas tanaman hortikultura yang banyak dikomsumsi manusia sebagai campuran bumbu masak. Selain itu juga dijual dalam berbagai bentuk olahan. Salah satu produk unggulan bawang merah lokal Palu adalah bawang goreng siap saji yang lazim disebut "Bawang Goreng Palu". Tercatat 36 industri kecil rumah tangga di Kota Palu yang mengolah bawang merah lokal Palu menjadi bawang goreng. Bawang goreng Palu memiliki tekstur padat, rasanya gurih serta aromanya khas sehingga banyak disenangi oleh masyarakat. Bawang goreng Palu laris sebagai oleh-oleh ke sejumlah daerah di Indonesia dan negara seperti Perancis, Malaysia dan China sehingga dikategorikan sebagai komoditi khas Sulawesi Tengah berdaya saing tinggi (Alam dkk., 2014).

Produksi bawang merah Lembah Palu baru mencapai 5,31 ton ha ${ }^{-1}$ (BPS Sulawesi Tengah, 2016), masih sangat rendah bila dibandingkan dengan potensi hasil yang dapat mencapai 9,7 ton/ha (Kementerian Pertanian RI, 2011). Salah satu kendala dalam upaya peningkatan produksi bawang merah Lembah Palu adalah adanya serangan penyakit busuk pangkal batang yang disebabkan oleh Fusarium oxsyporum $f$. sp. cepae. Gejala penyakit menyebabkan terjadinya pengeringan dan pengeritingan daun yang dimulai dari ujung serta pembusukan umbi atau perakaran, daun tanaman melintir, menguning, dan perakaran tanaman menjadi rapuh (Hadiwiyono \& Claudia, 2014).

Upaya pengendalian penyakit busuk pangkal batang yang dapat dilakukan adalah tindakan budidaya, antara lain dengan melakukan pemupukan menggunakan pupuk organik serta penggunaan agensia antagonis. Pemupukan merupakan salah satu tindakan dalam meningkatkan unsur hara pada tanah, baik langsung maupun tidak langsung sehingga ketersediaan nutrisi tanaman terpenuhi dengan baik. Unsur hara dapat berasal dari pupuk organik dan pupuk anorganik.

Pupuk organik merupakan salah satu bahan untuk memperbaiki sifat fisik, biologi dan kimia tanah untuk mendukung produktivitas tanaman. Penambahan bahan organik dalam tanah akan meningkatkan keragaman cendawaan, bakteri, mikro flora, dan mikro fauna tanah lainnya yang menguntungkan bagi tanaman (Rahman \& Nugroho, 2016).

Pupuk kandang merupakan salah satu bentuk pupuk organik yang banyak digunakan oleh petani (Khem dkk., 2018). Pupuk kandang mengandung vitamin, indole 3 -acetic acid (IAA), gibberellic acid (GA), dan mikroorganisme yang bermanfaat (Sreenivasa dkk., 2009).

Para peneliti telah memanfaatkan kotoran ternak sebagai kompos pupuk kandang untuk mensubtitusi pupuk kimia pada berbagai jenis budidaya tanaman seperti kompos pupuk 
kandang ayam pada tanaman kentang (Amara dkk., 2015), bawang merah (Kandil dkk., 2013; Mollah dkk., 2015; Falodun \& Egharevba, 2018). Kompos pupuk kandang sapi biasanya digunakan pada tanaman bawang merah (Lasmini dkk., 2019) dan tanaman tomat (Kalbani dkk., 2016) sedangkan kompos pupuk kandang kambing diaplikasikan pada jagung (Gitari, dkk., 2015) dan berbagai jenis tanaman sayuran (Mupondi dkk., 2010).

Kelemahan kompos pupuk kandang adalah proses pelepasan hara yang lambat (Sopha \& Uhan, 2013). Oleh karena itu untuk mendapatkan bahan organik yang tersedia dan menyediakan unsur hara lebih cepat serta bertepatan dengan saat dibutuhkan tanaman, perlu penambahan mikroorganisme pengurai (decomposer) yang dapat meningkatkan kandungan karbon organik tanah dan aktivitas mikroba dalam tanah. Trichoderma sp merupakan mikroorganisme dalam tanah yang dapat mempercepat dekomposisi bahan organik (Khatoon dkk., 2017). Selain itu juga dapat berperan sebagai agen biokontrol (Haneefat, dkk., 2012).

Efektivitas $T$. virens sebagai agen antagonis sangat dipengaruhi oleh dosis dan waktu aplikasi. Hasil Penelitian yang dilakukan oleh Fitriyani (2017), waktu aplikasi T. virens 7 hari sebelum tanam efektif dalam menekan penyakit layu Fusarium pada bawang merah dan menunjukkan bobot umbi kering perumpun tertinggi yaitu 70,30 gram.
Penelitian ini bertujuan untuk mengetahui pengaruh berbagai jenis kompos kotoran ternak yang didekomposisi oleh $T$. virens terhadap kejadian penyakit busuk pangkal batang dan produksi bawang merah lokal Lembah Palu.

\section{METODE}

Penelitian dilaksanakan di Laboratorium Hama dan Penyakit Tumbuhan, Fakultas Pertanian, Universitas Tadulako, Palu dan di lahan pertanaman bawang merah milik petani di Desa Oloboju, Kecamatan Sigi Biromaru, Kabupaten Sigi, Provinsi Sulawesi Tengah. Penelitian berlangsung pada bulan Maret sampai Agustus 2018.

Bahan yang digunakan adalah bawang merah lokal Lembah Palu, pupuk kandang sapi, kambing, ayam, pupuk organik petroganik dan T. virens. Alat yang digunakan adalah lampu bunsen, alkohol, stoples, pisau, timbangan, ember, cangkul, tugal, meteran dan kamera.

Penelitian menggunakan rancangan acak kelompok (RAK) yang terdiri atas 5 taraf jenis pupuk organik yang didekomposisi dengan $T$. virens yaitu:

$\mathrm{B}_{0}=$ Kontrol (tanpa perlakuan),

$\mathrm{B}_{1}=$ Pupuk kandang sapi 10 ton/ha $+T$. virens,

$\mathrm{B}_{2}=$ Pupuk kandang ayam 10 ton/ha $+T$. virens $\mathrm{B}_{3}=$ Pupuk kandang kambing 10 ton/ha $+T$. virens,

$\mathrm{B}_{4}=$ Pupuk organik petroganik 5 ton/ha $+T$. virens. 
Masing-masing perlakuan diulang 3 kali sehingga diperoleh 15 unit perlakuan. Aplikasi pupuk kandang diberikan satu minggu sebelum tanam, kemudian diberikan pupuk susulan $T$. virens dengan konsentrasi $100 \mathrm{~g} / 10 \mathrm{~L}$ air satu minggu setelah tanam dengan interval aplikasi 7 hari sekali sebanyak 5 kali aplikasi.

\section{Perbanyakan Trichoderma pada media jagung}

Perbanyakan Trichoderma virens menggunakan media jagung giling. Inokulum $T$. virens diperoleh dari Balai Penelitian Tanaman Industri Bogor (Indonesia) yang dikulturkan kembali menggunakan media Potato Dextrose Agar (PDA). Perbanyakan pada media jagung dilakukan dengan cara jagung digiling kasar kemudian dicuci hingga bersih. Setelah itu jagung dikukus selama 15 menit lalu dimasukkan ke dalam plastik tahan panas masing-masing sebanyak 100 gram. Selanjutnya dilakukan sterilisasi menggunakan autoclave pada suhu $121{ }^{\circ} \mathrm{C}$ dengan tekanan sebesar 1 atm selama 15 menit. Media jagung setelah dingin lalu diinkubasi dengan biakan $T$. virens dengan cara memasukkan sebanyak $0,5 \mathrm{ml}$ suspensi konidia hasil pengenceran sebesar $10^{-3}$ dari media PDA.

\section{Pengenceran suspensi jamur}

Media jagung yang telah ditutup miselium jamur Trichoderma dihomogenkan terlebih dahulu kemudian diambil dan dipisahkan dari media sebanyak 100 gram lalu diberikan sedikit akuades, kemudian miselium jamur diambil. Miselium jamur yang telah dipisahkan dari media dipindahkan ke dalam tabung reaksi yang berisi akuades sebanyak 9 $\mathrm{ml}$, kemudian di rotary mixer selama 1 menit. Tahapan ini menghasilkan tingkat pengenceran sebesar $10^{-1}$ Selanjutnya pada tingkat pengenceran $10^{-2}$ dilakukan dengan cara mengambil sebanyak $1 \mathrm{ml}$ suspensi pada tingkat pengenceran sebesar $10^{-1}$ dimasukkan ke dalam tabung reaksi yang berisi akuades sebanyak $9 \mathrm{ml}$. Demikian seterusnya dengan tahapan yang sama untuk mendapatkan tingkat pengenceran sebesar $10^{-5}$.

\section{Perhitungan kerapatan spora}

Setelah dilakukan pengenceran, kerapatan spora untuk setiap tingkat pengenceran dihitung menggunakan Neubauer di bawah mikroskop majemuk pada perbesaran $400 \mathrm{x}$. Kerapatan spora per $\mathrm{ml}$ dihitung dengan menggunakan rumus kerapatan spora (Gabriel \& Riyatno, 1989)

$$
C=\frac{t}{N \times 0,25} \times 10^{6}
$$

Keterangan :

$C \quad$ : kerapatan spora per ml larutan

$t \quad$ : jumlah total spora dalam kotak sampel yang diamati

$N \quad$ : jumlah kotak sampel (5 kotak besar $\times 16$ kotak kecil)

0,25 : faktor koreksi penggunaan kotak sampel skala kecil pada haemocytometer.

$10^{6}$ : Standar kerapatan spora yang baik (Direktorat Perlindungan Perkebunan Kementrian Pertanian, 2014)

\section{Pengolahan tanah}

Pengolahan tanah dilakukan dengan cara dibajak dengan hand traktor. Setelah diolah, 
lahan dibagi menjadi lima kelompok dengan, jarak antar petak $25 \mathrm{~cm}$. Setiap petak berukuran $2 \mathrm{~m} \times 3 \mathrm{~m}$ sebanyak 15 petak percobaan.

\section{Persiapan benih}

Bibit bawang yang digunakan adalah benih yang telah disimpan selama 2-3 bulan dari tanaman yang dipanen pada umur 90 hari.

\section{Penanaman}

Sebelum tanam benih bawang merah terlebih dahulu diseleksi dengan cara memilah benih yang baik, selanjutnya benih ditanam satu benih dengan jarak tanam $15 \mathrm{~cm} \times 20 \mathrm{~cm}$, sehingga perpetak terdapat 66 tanaman.

\section{Pemupukan}

Pemberian pupuk organik 1 minggu sebelum tanam pada tanaman bawang merah sesuai dengan dosis perlakuan, kemudian diberikan pupuk susulan yaitu $T$. virens dengan konsentrasi $100 \mathrm{~g} / \mathrm{L}$ satu minggu setelah tanaman, dengan interval aplikasi 7 hari sekali sebanyak 5 kali aplikasi.

\section{Pemeliharaan}

Pengendalian gulma dilakukan secara fisik dengan mencabut gulma kemudian dibenamkan kembali. Pengendalian dilakukan dengan menyesuaikan kondisi lapangan.

\section{Pengairan}

Penyiraman dilakukan sebanyak dua kali setiap hari yakni setiap pagi dan sore hari sampai tanaman berumur 10 hari. Selanjutnya frekuensi penyiraman dilakukan satu hari sekali sampai umur tanaman mencapai 50 hari.

\section{Panen}

Tanaman bawang merah dipanen pada umur 70 hari setelah tanam. Pemanenan dilakukan dengan mencabut seluruh bagian tanaman termasuk akar, batang dan daun.

\section{Pengamatan}

Variabel pengamatan yaitu intensitas serangan penyakit busuk pangkal batang dan hasil bawang merah. Pengamatan intensitas serangan penyakit dilakukan setiap minggu mulai minggu ke-3 sampai dengan minggu ke-7 setelah tanaman, sedangkan hasil bawang merah dilakukan pada saat panen. Intensitas serangan penyakit dihitung dengan rumus Hunter dkk. (1998)

$$
I=\frac{\sum(\mathrm{nxv})}{\mathrm{N} \times \mathrm{Z}} \times 100 \%
$$

\section{Keterangan :}

I : Intensitas serangan penyakit

$\mathrm{n} \quad$ : Jumlah tanaman yang diamati

$\mathrm{v}$ : Nilai skor untuk kategori tiap kerusakan

$\mathrm{N} \quad$ : Jumlah total sampel tanaman yang diamati

Z : Nilai skor kategori kerusakan yang tertinggi

Cara pemberian skor dilakukan sebagai berikut:

Skor 0 : Tidak ada kerusakan pada daun tanaman yang diamati

Skor 1 : Ada kerusakan 1\%-25\% pada daun tanaman yang diamati

Skor 2 : Ada kerusakan 26\%-50\% pada daun tanaman yang diamati

Skor 3 : Ada kerusakan 51\%-75\% pada daun tanaman yang diamati

Skor 4 : Ada kerusakan 76\%-100\% pada daun tanaman yang diamati 


\section{Analisis data}

Data hasil pengamatan dianalisis dengan menggunakan analisis keragaman (ANOVA) menggunakan software PAST (PAleontological STatistics) dan apabila menunjukkan pengaruh yang nyata selanjutnya diuji dengan merah dari berbagai waktu pengamatan menggunakan Uji Beda Nyata Terkecil (BNJ) 5\%. disajikan pada Tabel 1.

Tabel 1. Rata-rata kejadian penyakit busuk pangkal batang pada pertanaman bawang merah (\%)

\begin{tabular}{cccccc}
\hline \multirow{2}{*}{ Perlakuan } & \multicolumn{5}{c}{ Kejadian penyakit (\%) } \\
\cline { 2 - 6 } & $\mathbf{3}$ MST & $\mathbf{4 ~ M S T}$ & $\mathbf{5 ~ M S T}$ & $\mathbf{6 ~ M S T}$ & $\mathbf{7 ~ M S T}$ \\
\hline B0 & $5,61 \pm 0,19 \mathrm{a}$ & $6,30 \pm 1,22 \mathrm{a}$ & $4,16 \pm 0,32 \mathrm{a}$ & $3,93 \pm 1,62 \mathrm{a}$ & $2,89 \pm 0,35 \mathrm{a}$ \\
B1 & $1,88 \pm 1,00 \mathrm{~b}$ & $1,70 \pm 0,92 \mathrm{~b}$ & $2,14 \pm 0,43 \mathrm{~b}$ & $1,45 \pm 0,52 \mathrm{~b}$ & $0,98 \pm 0,53 \mathrm{~b}$ \\
B2 & $2,79 \pm 1,17 \mathrm{~b}$ & $3,57 \pm 0,61 \mathrm{bc}$ & $3,53 \pm 0,81 \mathrm{a}$ & $2,34 \pm 0,78 \mathrm{~b}$ & $2,02 \pm 0,41 \mathrm{a}$ \\
B3 & $2,76 \pm 0,40 \mathrm{~b}$ & $3,27 \pm 1,51 \mathrm{bc}$ & $2,50 \pm 0,90 \mathrm{~b}$ & $1,62 \pm 0,74 \mathrm{~b}$ & $1,26 \pm 0,61 \mathrm{~b}$ \\
B4 & $3,87 \pm 1,84 \mathrm{ab}$ & $4,87 \pm 1,53 \mathrm{c}$ & $3,60 \pm 0,81 \mathrm{a}$ & $2,44 \pm 0,86 \mathrm{~b}$ & $2,46 \pm 0,41 \mathrm{a}$ \\
\hline BNJ 5\% & 2,33 & 2,35 & 1,30 & 1,58 & 0,97 \\
\hline
\end{tabular}

Keterangan: angka yang diikuti oleh huruf sama pada kolom yang sama menunjukkan tidak berbeda nyata pada uji BNJ 5\%; MST = minggu setelah tanam

Hasil uji BNJ 5\% (Tabel 1.) menujukkan bahwa perlakuan pupuk kotoran sapi yang didekomposisi dengan T. virens (B1) menghasilkan kejadian penyakit busuk pangkal batang terendah pada pengamatan 3 MST, berbeda nyata dengan perlakuan BO tetapi tidak berbeda dengan perlakuan lainnya. Pengamatan 4 MST perlakuan B1 berbeda nyata dengan B0 dan B4 tetapi tidak berbeda dengan perlakuan B2 dan B3. Pengamatan 5 MST perlakuan B1 berbeda nyata dengan perlakuan B0, B2 dan B4, akan tetapi tidak berbeda nyata dengan perlakuan B3. Pengamatan 6 MST perlakuan B1 berbeda nyata dengan perlakuan B0, tetapi tidak berbeda nyata dengan perlakuan lainnya, serta pada pengamatan 7 MST perlakuan B1 berbeda nyata dengan perlakuan B0, B2 dan B4 tetapi tidak berbeda nyata dengan perlakuan B3. Hasil perhitungan kerapatan spora jamur antagonis T. virens pada konsentrasi $100 \mathrm{~g}$ yaitu sebesar $12,16 \times 10^{6}$.

\section{Produksi bawang merah}

Produksi bawang merah pada berbagai aplikasi pupuk kompos kotoran ternak yang didekomposisi dengan $T$. virens dapat dilihat pada Tabel 2. 
Tabel 2. Rata-rata produksi bawang merah (ton/ha)

\begin{tabular}{cc}
\hline Perlakuan & Produksi (ton/ha) \\
\hline B0 & $4,09 \pm 0,17 \mathrm{~b}$ \\
B1 & $7,48 \pm 2,06 \mathrm{a}$ \\
B2 & $5,92 \pm 1,28 \mathrm{ab}$ \\
B3 & $6,13 \pm 1,42 \mathrm{ab}$ \\
B4 & $6,06 \pm 0,52 \mathrm{ab}$ \\
\hline BNJ 5\% & 2,30 \\
\hline
\end{tabular}

Keterangan: angka-angka yang diikuti oleh huruf sama pada kolom yang sama menunjukkan tidak berbeda nyata pada uji BNJ 5\%.

Hasil uji BNJ 5\% (Tabel 2.) menunjukkan bahwa hasil panen bawang merah yang paling tinggi diperoleh pada perlakuan B1 yakni 7,48 ton/ha berbeda nyata perlakuan B0, tetapi tidak berbeda nyata dengan perlakuan lainnya, sedangkan yang paling rendah adalah perlakuan B0 yakni 4,09 ton/ha meskipun tidak berbeda nyata dengan perlakuan B2, B3, dan B4.

\section{Pembahasan}

Hasil pengamatan menunjukkan bahwa dari penggunaan berbagai jenis pupuk kandang yang didekomposisi dengan $T$. virens, pupuk kandang sapi $+T$. virens (B1) memberikan pengaruh lebih baik hampir pada semua parameter pengamatan, dengan rata-rata penyakit busuk pangkal batang bawang merah sebesar $1.20 \%$ pada waktu pengamatan 7 MST, dan produksi bawang merah sebesar 7.48 ton/ha.

Perlakuan pupuk kandang sapi (B1) yang didekomposisi dengan $T$. virens cenderung memberikan pengaruh lebih baik pada semua parameter pengamatan, dimana pada perlakuan tersebut intensitas penyakit busuk pangkal batang (Fusarium oxysporum) rendah, sehingga dengan hal tersebut dapat meningkatkan hasil bawang merah. Hal ini diduga karena pupuk kandang kotoran sapi yang didekomposisi dengan $T$. virens dapat menyediakan dan memberikan suplai hara yang seimbang yang dibutuhkan oleh tanaman bawang merah selama pertumbuhannya sehingga dapat mempertahankan dirinya terhadap serangan hama dan penyakit. Dalam penelitian ini konsentrasi $T$. virens yang diaplikasikan sebagai pupuk dan bioprotektan adalah sebesar $100 \mathrm{~g} / 10 \mathrm{~L}$ air per satu kali aplikasi merupakan konsentrasi yang diperoleh melalui uji pendahuluan. Galindez dkk. (2018) menyatakan bahwa pemberian inokulan mikroba Trichoderma sp. pada pupuk organik dapat meningkatkan hasil umbi bawang merah.

Suplai hara yang seimbang pada pupuk kandang sapi disebabkan karena pupuk kandang sapi mengandung unsur hara makro ( $N$, P dan K) yang sangat dibutuhkan oleh tanaman selama proses pertumbuhannya. Hal tersebut didukung pendapat Gunadi (2009) bahwa unsur kalium (K) berfungsi untuk pembentukan protein dan karbohidrat pada tanaman bawang merah serta dapat 
meningkatkan ketahanan tanaman terhadap serangan hama penyakit dan dapat meningkatkan kualitas umbi. Pernyataan tersebut juga sejalan dengan Razzaque dkk. (1990) yang menyatakan bahwa pemberian pupuk kalium pada tanaman bawang merah dapat menyebabkan tanaman tidak mudah rebah, lebih tahan terhadap penyakit dan cekaman lingkungan. Menurut Behairy dkk. (2015) dosis optimum pupuk kalium pada tanaman bawang merah adalah sebesar 300 $\mathrm{kg} / \mathrm{ha}$

Suplai hara yang seimbang pada pupuk kandang sapi disebabkan karena pupuk kandang sapi mengandung unsur hara makro (N, P dan $\mathrm{K}$ ) yang sangat dibutuhkan oleh tanaman selama proses pertumbuhannya. Hal tersebut didukung pendapat Gunadi (2009) bahwa unsur kalium (K) berfungsi untuk pembentukan protein dan karbohidrat pada tanaman bawang merah serta dapat meningkatkan ketahanan tanaman terhadap serangan hama penyakit dan dapat meningkatkan kualitas umbi. Pernyataan tersebut juga sejalan dengan Razzaque dkk. (1990) yang menyatakan bahwa pemberian pupuk kalium pada tanaman bawang merah dapat menyebabkan tanaman tidak mudah rebah, lebih tahan terhadap penyakit dan cekaman lingkungan. Menurut Behairy dkk. (2015) dosis optimum pupuk kalium pada tanaman bawang merah adalah sebesar 300 $\mathrm{kg} / \mathrm{ha}$.
Dengan adanya kecukupan $\mathrm{K}$ dapat meningkatkan terbentuknya senyawa lignin yang lebih tebal sehingga dinding sel menjadi lebih kuat dan dapat melindungi tanaman dari gangguan luar (Rosidah, 2016). Dinyatakan pula oleh Nurhayati (2008) bahwa pemberian K dosis 6 gram dapat meningkatkan ketahanan tanaman terhadap serangan Cercospora $s p$ pada kacang tanah, hal ini disebabkan karena unsur Kalium dapat meningkatkan ketahanan mekanik tanaman dengan memperkuat jaringan tanaman serta mempertebal dinding epidermis.

Secara umum pemberian $T$. virens pada pupuk kandang memperlihatkan pertumbuhan bawang merah lebih baik dibandingkan dengan yang tidak diberikan T. virens. $\mathrm{Hal}$ ini disebabkan karena dengan pemberian $T$ virens mampu menghasilkan miselium yang berasal dari koloni yang dapat menekan perkembangan jamur yang menyebabkan berkurangnya hasil metabolisme tanaman bagi patogen. Selain itu T. virens dapat bertindak sebagai biodekomposer yang dapat memperbaiki sifatsifat tanah sehingga dapat menguntungkan bibit tanaman (Khatoon dkk., 2017).

\section{Trichoderma}

sp.

termasuk mikroorganisme saprofit yang bertindak sebagai biodekomposer bahan organik yang mengandung serat, lignin, dan senyawa organik yang mengandung nitrogen dan karbon dari bahan organik (Soesanto \& Prihatiningsih, 2008). Spesies T. virens disamping sebagai 
organisme pengurai, dapat pula berfungsi sebagai agens hayati. T. virens sebagai agens hayati bekerja berdasarkan mekanisme antagonis yang dimilikinya. Purwantisari \& Hastuti (2009) menyatakan bahwa Trichoderma sp. merupakan cendawaan parasit yang dapat menyerang dan mengambil nutrisi dari cendawaan lain. Biakan Trichoderma sp. dalam media aplikatif seperti dedak dapat diberikan ke area pertanaman dan berlaku sebagai biodekomposer, mendekomposisi limbah organik menjadi kompos yang bermutu serta dapat berlaku sebagai biofungisida. Trichoderma sp. dapat menghambat pertumbuhan beberapa jamur penyebab penyakit pada tanaman antara lain Rigidiforus lignosus, F. oxysporum, Rizoctonia solani, dan Sclerotium rolfsii.

Pada semua unit percobaan jumlah spora jamur antagonis yang diujikan memperlihatkan pangaruh pada hasil pengamatan. Hasil perhitungan spora jamur antagonis $T$. virens pada konsentrasi 100 gram yaitu sebesar $12,16 \times 10^{6}$. Jumlah spora tersebut mungkin masih kurang dalam menghambat maupun menekan perkembangan jamur $F$. oxysporum pada bawang merah.

T. virens mengeluarkan antibiotik dari senyawa viridiol phytotoxin yang dapat menghambat perkembangan patogen, sebagai parasit patogen dengan penetrasi langsung dan juga lebih cepat dalam mempergunakan $\mathrm{O}_{2}$, air dan nutrisi sehingga mampu bersaing dengan patogen (Haneefat dkk., 2012). Efektivitas $T$. virens sebagai agen antagonis sangat dipengaruhi oleh dosis dan waktu aplikasi. Hasil Penelitian yang dilakukan oleh Fitriyani (2017), waktu aplikasi Trichoderma sp. selama 7 hari sebelum tanam efektif dalam menekan penyakit layu Fusarium pada bawang merah dan menunjukkan bobot umbi kering perumpun tertinggi yaitu 70,30 gram.

\section{KESIMPULAN}

Berdasarkan hasil yang diperoleh dalam penelitian ini dapat disimpulkan bahwa aplikasi pupuk kandang sapi yang didekomposisi dengan Trichoderma virens dapat menekan intensitas serangan penyakit busuk pangkal batang pada tanaman bawang merah Lembah Palu yakni 5,61\% menjadi 1,88\% (minggu ke-3) dan 2,89\% menjadi 0,98\% (minggu ke7), serta meningkatkan produksi bawang merah yakni dari 4,09 ton/ha (tanpa aplikasi pupuk kandang) menjadi 7,48 ton/ha.

\section{UCAPAN TERIMA KASIH}

Artikel ini merupakan bagian dari Penelitian Riset Terapan yang didanai oleh Direktorat Riset dan Pengabdian Kepada Masyarakat Direktorat Jenderal Penguatan Riset dan Pengembangan Kementerian Riset, Teknologi dan Pendidikan Tinggi Sesuai dengan Kontrak Penelitian Nomor: 097/SP2H/LT/DRPM/2018, tanggal 26 Maret 2018. 


\section{DAFTAR PUSTAKA}

Alam, N., Rostiati, \& Muhardi (2014). Sifat fisikkimia dan organoleptik bawang goreng Palu pada berbagai frekuensi pemakaian minyak goreng. Agritech, 34(4), 390-398.

Amara, D. G., Kherraz, K., Nagaz, K., \& Senoussi, M. M. (2015). Effect of chicken manure and organic nitrogen levels on yielding and antioxidant content of tuber potato at Algeria Sahara. International Journal of Agriculture Innovations and Research, 4(1), 17-21.

BPS Sulawesi Tengah (2016). Provinsi Sulawesi Tengah dalam angka 2016: Luas panen, produksi dan hasil per hektar tanaman sayuran menurut kabupaten/kota dan jenis sayuran di Provinsi Sulawesi Tengah 2011-2015. BPS Provinsi Sulawesi Tengah.

Behairy, A. G., Mahmoud, A. R., Shafeek, M. R., Ali, A. H., \& Hafez, M. M. (2015). Growth, yield and bulb quality of onion plants (Allium cepa L.) as affected by foliar and soil application of potassium. Middle East J. Agric. Res, 4(1), 60-66.

Direktorat Perlindungan Perkebunan Kementerian Pertanian RI. (2014). Pedoman uji mutu dan uji efikasi lapangan agens pengendali hayati (APH). Jakarta.

Falodun, E. J., \& Egharevba, R. (2018). Influence of poultry manure rates and spacing on growth, yield, nutrient concentration, uptake and proximate composition of onion (Allium cepa L.). Notulae Scientia Biologicae, 10(1), 117-123. https://doi.org/10.15835/nsb10110230

Fitriyani (2017). Efektifitas berbagai dosis dan waktu aplikasi trichoderma sp terhadap penyakit layu fusarium pada tanaman bawang merah [skripsi, UIN Sunan Gunung Djati Bandung]. http://digilib.uinsgd.ac.id/id/eprint/6793.

Gabriel, B.P. \& Riyatno (1989). Metarhizium anisopliae (Metch) sor: Taksonomi, patologi, produksi dan aplikasinya. Direktorat perlindungan tanaman perkebunan. Departemen Pertanian.

Galindez, J.L., Porciuncula, F.L., Pascua, M.P., Claus, S.M., Lopez, L.L.M.A. (2016). Performance of red onion (bulb type) in fully converted organic area as affected by frequency of organic fertilizer application combined with Trichoderma spp. Journal of Agricultural Science and Technology B, 6(1), 10-17. https://doi.org/10.17265/21616264/2016.01.002

Gitari, H.I., Benson, E. M., \& Benjamin, O. D. (2015). Effect of lime and goat manure on soil acidity and maize (zea mays) growth parameters at Kavutiri, Embu CountyCentral Kenya. Journal of Soil Science and Environmental Management, 6(10), 275283.

https://doi.org/10.5897/jssem15.0509

Gunadi, N. (2009). Kalium sulfat dan kalium klorida sebagai sumber pupuk kalium pada tanaman bawang merah. Jurnal Hortikultura, 19(2), 174-185. https://doi.org/10.21082/jhort.v19n2.200 9.p

Hadiwiyono, S., \& Claudia, S. S. (2014). Jamur pelarut fosfat untuk menekan penyakit moler (Fusarium oxsyporum f. sp.cepae) dan menigkatkan pertumbuhan bawang merah. Jurnal of Soil Sceince and Agroclimatology 11(2), 130-138.

Haneefat, O., Sobowale, A.A., Ilusanya, O.A.F., Feyisola, R. . (2012). The influence of glomus mosseae and trichoderma harzianum on phytohormone production in soybeans (Glycine max L. Merr) planted in sterilized and unsterilized soils. American Journal of Experimental Agriculture, 2(3), 516-524. https://doi.org/10.9734/ajea/2012/910

Hunter, W.B., Hiebert, E., Webb, S.E., Tsai,J.H., \& Polston, J.E. (1998). Ocation of eminivirus In the whitefly Bemisia tabaci (Homoptera: Aleyrodidae). Plant Disease. 82, 1147-1511. 
Kalbani, F. O. S. A., Salem, M. A., Cheruth, A. J., Kurup, S. S., \& Senthilkumar, A. (2016). Effect of some organic fertilizers on growth, yield and quality of tomato (Solanum lycopersicum). International Letters of Natural Sciences, 53, 1-9. https://doi.org/10.18052/www.scipress.c om/ilns.53.1

Kandil, A. A., Sharief, A. E., \& Fathalla, F. H. (2013). Effect of organic and mineral fertilizers on vegetative growth, bulb yield and quality of onion cultivars. Crop Production, 2(3), 91-100.

Kementerian Pertanian RI (2011). Deskripsi Varietas Bawang Merah Lembah Palu. Lampiran Keputusan Menteri Pertanian Nomor : 1843/Kpts/SR.120/4/2011. Tgl 8 April 2011. Jakarta.

Khatoon, H., Solanki, P., Narayan, M., Tewari, L., Rai, J., \& Hina Khatoon, C. (2017). Role of microbes in organic carbon decomposition and maintenance of soil ecosystem. International Journal of Chemical Studies, 5(6), 1648-1656. http://www.chemijournal.com/archives/ 2017/vol5issue6/PartW/5-6-133-734.pdf

Khem, B., Hirai, Y., Yamakawa, T., Mori, Y., Inoue, E., Okayasu, T., \& Mitsuoka, M. (2018). Effects of different application methods of fertilizer and manure on soil chemical properties and yield in whole crop rice cultivation. Soil Science and Plant Nutrition, 64(3), 406-414. https://doi.org/10.1080/00380768.2018. 1443399

Lasmini, S. A., Wahyudi, I., Rosmini, R., Nasir, B., \& Edy, N. (2019). Combined application of mulches and organic fertilizers enhance shallot production in dryland. Agronomy Research, 17(1), 165-175. https://doi.org/10.15159/AR.19.017

Mollah, M. R. A., Ali, M. A., Ahmad, M., Hassan, M. K., \& Prodhan, M. Z. H. (2015). Effect of organic manures on the yield and quality of true seeds of onion. International Journal of Applied Sciences and Biotechnology, 3(2), 162-166. https://doi.org/10.3126/ijasbt.v3i2.12279

Mupondi, L. T., Mnkeni, P. N. S., \& Muchaonyerwa, P. (2010). Effect of pine bark goat manure medium on seedling growth and N, P, K concentration of various vegetables. South African Journal of Plant and Soil, 27(4), 305-311. https://doi.org/10.1080/02571862.2010. 10639999

Nurhayati (2008). Pengaruh pupuk kalium pada ketahanan kacang tanah terhadap bercak daun cercospora. Agriculture, 13(3), 446450.

Purwantisari, S., \& Hastuti, R. (2009). Uji antagonisme jamur patogen phytophthora infestans penyebab penyakit busuk daun dan umbi tanaman kentang dengan menggunakan Trichoderma spp. Isolat Lokal. Bioma, 11(1), 24-32.

Rahman, A.S., \& Nugroho, A. (2016). Kajian hasil bawang merah (Allium ascolonicum L.) di lahan dan polybag dengan pemberian berbagai macam dan dosis pupuk organik. Jurnal Produksi Tanaman, 4(7), 538-546.

Razzaque, A.H.M., Ali, M.I., \& Habibullah, A.K.M. (1990). Response of boror rice to potassium application in two soil of Bangladesh. Journal of Soil Science, 21(1), 26-29

Rosidah, A. (2016). Respon pemberian pupuk kalium terhadap ketahanan penyakit layu bakteri dan karakter agronomi pada tanaman tomat (Solanum lycopersicum L) Seminar Nasional Hasil Penelitian. Universitas Islam Malang. $6 p$

Sopha, G. A., \& Uhan, T. S. (2013). Application of liquid organic fertilizer from city waste on reduce urea application on Chinese mustard (Brassica juncea L) cultivation. $A A B$ Bioflux, 5(1), 39-44. http://www.aab.bioflux.com.ro 
Sreenivasa, M. N., Naik, N., \& Bhat, S. N. (2009). Soesanto, L., \& Prihatiningsih, N. (2008). Beejamrutha: A source for beneficial bacteria. Karnataka Journal of Penekanan beberapa mikroorganisme Agricultural Sciences, 22(1), 1038-1040. antagonis terhadap penyakit layu Fusarium gladiol. Agrivita 30(1), 75-83 